\title{
CULTURAL LANDSCAPE: A BRIDGE BETWEEN DEFORESTATION AND LOCAL COMMUNITY?
}

\author{
PUTU INDRA CHRISTIAWAN
}

Universitas Pendidikan Ganesha, Indonesia, e-mail: indra.christiawan@undiksha.ac.id

Received: $4^{\text {th }}$ May 2017, Accepted: $3^{\text {rd }}$ August 2018

\begin{abstract}
Deforestation is a serious threat to areas with large forest resources. Indonesia as a tropical country has a vast forest in every region. Weak supervision leads to more deforestation cases being carried out by local communities, with negative consequences that directly lead to the local community. The involvement of local communities in managing forests is absolutely necessary. The study in this paper shows that local people have learned hard from the consequences of deforestation, and then learned to live harmoniously with nature in their local wisdom. Based on the results of the study shows that: (1) deforestation gives little benefit and is temporary compared to the prolonged negative impacts in the form of drought disaster, and on the other hand, (2) deforestation is a driving force in the creation of cultural landscape that makes people in Selat Village, Buleleng Regency, Bali Province is able to live harmoniously with the God's, human and with the environment.
\end{abstract}

Keywords: Deforestation; Local Community; Cultural Landscape; Local Wisdom

\section{INTRODUCTION}

Indonesia has forest resources with vast forests. Indonesia's forest area has a wealth of mega-biodiversity of 27,500 species of flowering plants, 1,539 species of reptiles and amphibians, $12 \%$ of world mammals, $25 \%$ of world fish species, and $17 \%$ of the world's most important bird species as the world's germplasm (Forest Watch Indonesia, 2001). Coupled with the natural beauty and enormous environmental and social services, it shows that Indonesia's forest area with various forest resources and its multiplier effects has potentially high economic value.

However, the state forest area of 120.3 million hectares and listed as the third largest forest after Brazil and the Republic of Congo, is in critical condition. Indonesia's tropical forest resources are very rich with a variety of flora-fauna life and its natural wealth is deforested. It is noted that Indonesia is the country with the greatest level of forest destruction in the world. On another note, Indonesia is a green country ranked in 102 of 149 countries in the world that owns forests based on their environmental performance. Therefore, forest resources must be immediately rectified with a comprehensive concept, as well as with high commitment from all stakeholders who manage or utilize it.

In the 1970s Indonesia's forests were once referred to as 'green', which is capable of sustaining the country's economy by contributing $5.3 \%$ to Gross Domestic Product growth (Yamani, 2011). However, the current contribution of the forestry sector to GDP shows 
declining value. The drastic decline in figures shows that Indonesia's forest is now experiencing deforestation due to damage. On the other hand, forest fires continue to occur with a smoke that is technically difficult to control. Moreover, forestry crime in the form of illegal logging and timber business, which is increasingly widespread and massive threatens the existence of forest resources in Indonesia. Indonesia's forest resources not only have a major ecological and economic function, but also social functions that are vital to life.

Indonesia is a country with the most severe deforestation in the world. If drawn a century backward, Indonesia has lost 15.79 million hectares of tropical forests. According to the Ministry of Forestry and Forestry Ministry of Forestry statistics in 2015 (Ministry of Forestry, 2015), the deforestation rate in Indonesia in three periods decreased by 2 million hectares per year during the 1980-1990s, around 1.5 million per year during 2000-2010 and around 1.1 Million hectares in the period 2010-2014. Although this figure has shown a decline, but the hazard of deforestation is still threatening from irresponsible production and consumption patterns. The greatest threat to Indonesia's forests is the conversion of forests into plantations, illegal logging, encroachment, forest fires and unsustainable forest exploitation for residential and industrial development.

Deforestation is a change in land cover conditions from forests to non-forests (including changes to plantations, settlements, industrial estates, etc.). Deforestation is the permanent destruction of forests in order to make the land available for other uses. Deforestation is generally due to the urging of land convergence for settlements, infrastructure and timber harvesting for industry. Sasaki et al., (2011) research found about 10 variables that triggered the occurrence of deforestation: (1) land sale, (2) settlement development, (3) opening of fields/gardens, (4) searching for firewood, (5) natural forest fires, (6) burning for land preparation, (7) illegal logging for commercial, (8) illegal logging for local needs, (9) plantation development and (10) natural disaster. Setiawan et. al., (2015) formulated a deforestation model using logistic regression showing two main factors driving deforestation which consist of: (1) accessibility factor i.e. distance from road, distance from river, distance from forest edge, distance from Settlement and distance from mixed dryland farming, as well as social factors i.e. population density and biophysics i.e., elevation and slope. In other cases, poverty is a major driver of deforestation, as well as unemployment, land tenure claims, proximity to forests, forestry services, household needs and disregard for government regulations or policies (Otieno \& Buyinza, 2010). In addition, land conversion as a form of deforestation is due to land clearing for plantations, agriculture, livestock and mining

Few studies have emphasized the involvement of local communities with local knowledge to control deforestation. Theoretically, local communities and forests have an inseparable relationship. Local people depend on forest resources for life, and the sustainability of forest ecology is strongly influenced by the activities of the local people. The process of local community living related to the forest has been accumulated experience in management for mutual living and inter-independence as the cultural landscape (Burirat et al., 2010).

Patten (2016) introduces the concept of the correlation of space (nature), man and culture, including the processes of change occurring within the natural space, either as a result of human reactions to nature as well as the consequences of nature and human behavior. Patten (2016) defines culture as everything that results from human reactions to nature and life, including the changes and factors of the factors that lead to the change. People use their minds to preserve life, to build and to develop life, so that they not only surrender to nature, but respond to natural pressures with the act of organizing or even changing nature, or simply articulating the circumstances in which they live. Culture landscape is thus seen as the result of human action and reaction in contact with the natural environment. 
In its development, the meaning of culture landscape can be an essential policy and strategy to direct the cultural process towards positive instrumental functions, and to prevent such instrumental functions from turning toward functions that endanger the sustainability of human life. This conception builds a theoretical framework of the cultural landscape as a form of synergy between nature and man. This theoretical framework positions nature and human beings as a component that determines the existence and meaning, or even the use of culture in human life. One of the cultural landscapes that has managed to control deforestation is local wisdom owned by local communities in restoring the conservation of Puncak Landep Protection Forest, Selat Village, Sukasada District, Buleleng Regency, Bali Province.

The focus in this study is the exploration of sustainable forest management based on local community. The specific objectives of this study are:

- To analyze of how deforestation affected local life

- $\quad$ To study of how they implemented their local wisdom to protect the forest from deforestation in the Puncak Landep Protection Forest in Selat Village, Sukasada District, Buleleng Regency, Bali Province.

\section{MATERIALS AND METHODS}

This research uses descriptive research design which is based on community activity of forest area in Selat Village. The variables analyzed in this study are related to the perception and cultural landscape of forest area in Selat Village, Sukasada District, Buleleng Regency. The target groups are community leaders and people who live in the directly adjacent to protected forest areas. These were derived through the purposive sampling.

The data collection in this study consists of 2 techniques. First, structured interview techniques to target groups to get information about people's perceptions of the cultural landscape to control deforestation. Second, by observation technique by observing the cultural landscape contained in the location of the study directly. The data have been analyzed descriptively qualitative. Descriptive analysis to reach conclusion from the cancrete data or perceived evidences in the practice of community forestry.

\section{RESULT AND DISCCUSSION}

\section{How deforestation affected local community life?}

The Protected Forest in the Selat Village has been deforested. Deforestation in the protected forest is in the form of forest encroachment. Records of the history of forest destruction in forest areas in the Selat Village indicate that in 1988 until 1999 there had been forest encroachment around the Puncak Landep Protection Forest area. This forest encroachment activity results in large ecosystem damage, a total of 50 ha of land in the protected forest is recorded as being completely depleted. The location of protected forests that experienced the worst level of damage occurred in Sekar Sari Hamlet and Gunung Puncak Hamlet in the northern part of the Puncak Landep Protection Forest. One of the Puncak Landep protected forest areas that have been deforested due to forest encroachment is shown in Fig. 1. 


\section{Fig. 1: Past deforestation by local communities}

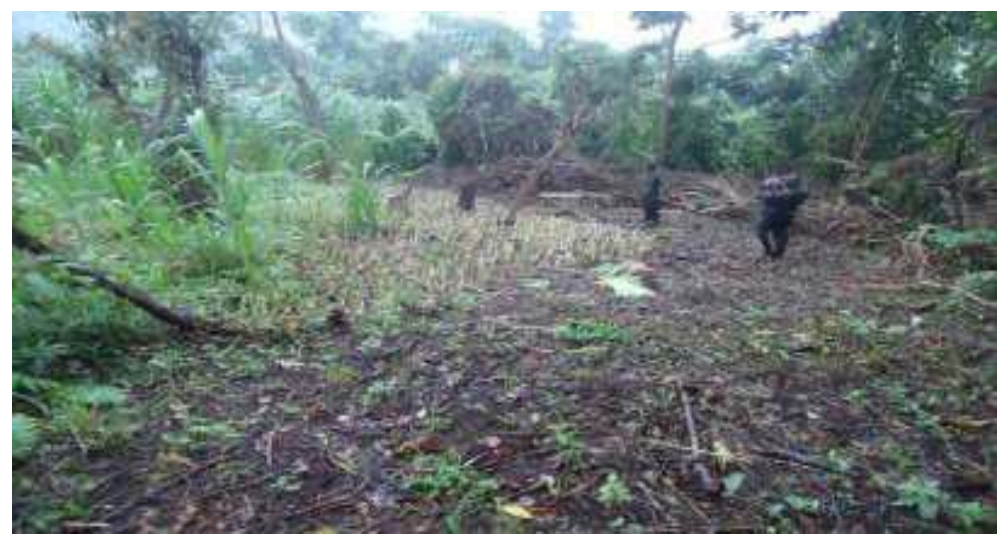

Ironically, forest encroachment is carried out by local people who live around the forest. The results of the causes of community encroachment activities were poverty. A poverty that encodes local communities around protected forest areas encourages them to penetrate the forest.

In the beginning, the absence of shelter able to accommodate all their family members, forcing them to cut down trees to look for the wood. Wood encroachment of forest is used as a base for building a residence. The sense of security felt by forest encroachers due to the absence of legal or customary sanctions encourages them to penetrate the forest further in. At that time, the reason they were venturing into the forest was to build a house but to be sold to external parties who offered high prices. In this phase, they have moved from the reasons from a subsistence to a more commercial direction. If examined in more depth, the phenomenon of illegal transactions of timber purchases involving local communities with external parties is very complicated, and already like a tangled thread.

It is very difficult to identify the chronology of the transaction. Not even a single record is found, which can lead to a particular subject, both from the seller and the buyer. Illegal transactions that have lasted for approximately ten years have changed the physical appearance of the forest, as well as the social appearance of some local communities, but still cannot be used as a valid indicator, which shows the relationship between deforestation and the improvement of the welfare of some communities at that time.

In other parts, it was noted that deforestation that occurred in the Landep Protection Forest also occurred due to agricultural activities. Most of the community's livelihoods in Selat Village are farmers. Farmers in the Selat Village during this period were traditional farmers, who had a shifting agricultural system (Sunderlin \& Resosudarmo, 1997). Traditional agricultural activities with a shifting cultivation system require farmers to always open new land to be used as agricultural land when agricultural land cultivated by previous farmers has exceeded the carrying capacity of agricultural production. The land cleared to meet the agricultural needs of the shifting cultivation system is a land in the protected forest area itself. The fundamental difference between forest encroachment and land clearing for agriculture in the context of deforestation lies in the chosen location. If forest encroachment is carried out inside the forest, the clearing of forest land for agriculture is carried out on the outside of the forest. Although different subjects, motives, and locations, these two activities caused the same forest damage.

Deforestation due to forest encroachment and clearing of forest land ultimately has a negative impact, which is not only felt by the people living near the forest and the farmers 
who open forest land, but also by the whole community in the Selat Village. Drought is a gift given by the forest to all people in the Selat Village.

Drought problems are common in tropical countries that have two types of seasons. Drought is a phenomenon that is identical to the dry season. However, the drought experienced by the community in the Selat Village occurs almost as long and even exceeds the dry season period. Ecologically, the drought that occurs in Selat Village is caused by the inability of the forest to collect and purify rainwater during the rainy season and release it slowly in the dry season.

Water for a majority of Hindus in the Selat Village is not only seen as a necessity for everyday life but also necessary for prayer facilities (Sardiana \& Dinata, 2010). Not only humans, livestock and plants grown by the community cannot grow properly. The scarcity of clean water coupled with hot weather conditions is a sign of natural wrath on humans around protected forest areas. On the other hand, the inability of the Hindu community in the Selat Village to carry out prayer activities well further strengthens this view.

The threat of human health, the death of livestock and crop destruction encourage local people in Selat Village to conduct self-interception. Through the meeting mechanism, all villagers customarily produce agreements, one of which is the cessation of forest encroachment and the clearing of forest land for agriculture. In the suit, it is also planned to build pelinggih (sacred building in the middle of the forest), and form a security unit to guard the forest. This agreement is also implemented and used as a guide to living in harmony with nature, especially with the forest. This guidance of life is the ultimate local wisdom, which until now has been firmly exercised by the people of Selat Village.

\section{How the local community implemented their local wisdom to protect the forest?}

First, humans exploit nature and respond to natural pressures. Secondly, nature provides itself for human use, and nature can also put pressure on people. Nature as the physical element of Balinese culture, which is a container of Balinese human life, puts pressure on the Balinese man, articulated by a Balinese man, and serves as a trigger of Balinese culture. Humans are Balinese cultural actors, serving as creators, maintainers, and managers.

Humans in every activity is strongly influenced by the physical condition of its territory and social community (Christiawan \& Lestari, 2015). The relationship between communities in Selat Village and protected forests strengthens the reciprocal relationship between human activities and natural conditions, and natural conditions with human adaptation. Bali's human adaptation to natural conditions is a human effort to maintain their life and livelihood while maintaining environmental sustainability.

Communities in Selat Village believe that the activities of forest encroachment and land clearing in forest areas are wrong, and the drought itself is a negative impact caused by themselves. They also believe that if they maintain the preservation of protected forests, then they will also maintain their survival and future generations. The efforts of local communities in maintaining the preservation of protected forests are contained in the form of local wisdom that they carry out. The local wisdom of the Selat Village community is a tangible manifestation of the cultural landscape created by deforestation, and created to prevent deforestation in traditional cultures.

Local wisdom created by Balinese people, especially the people in Selat Village to protect and protect forest areas from deforestation is by building shrines in the forest, and the establishment of forest guards security units, and choosing trees that are considered to have high spiritual value to be subjected to saput poleng or black-white cloth as a symbol of holiness. The black and white cloth is not only worn on trees that are considered to have high spiritual value, but also in the holy places that are built and worn by the guards in charge of 
protecting and protecting protected forest areas. This black and white fabric has the meaning of dualism. It is a philosophical value indicating the division of two pairs in a society believed by Hindus in Bali. This fabric has a philosophical meaning which denotes the division of two, ie good (positive) and bad (negative). The white color is identical to the consciousness or black color symbolizes the inhibitor. The use of black white clothes on these three elements has a different function.

\section{The place of worship in the forest}

The results of interviews with community leaders revealed that the sacred building that was built was a spiritual facility that the community believed in Selat Village as a place of worship. This place of worship is a sacred place intended to give thanks and gratitude to the Hindu community for the gift that God has given through various resources contained in the protected forest, and also pray that they are always protected and avoided from the drought that has struck the Selat Village. The real form of the worship process is to offer offerings that are done every full moon (full/perfect month) and tilem (dead month). The worship is intended to ensure that resources in protected forests can be utilized by the community in Selat Village in a sustainable manner. The existence of this place of worship is very preserved and sanctified. This is because the place of worship is one of the manifestations of a harmonious relationship between humans and God.

The place of worship in this case not only serves as a place for offering offerings but also serves as a protector for protected forests invisible (Hidayati, 2016). The results of interviews with local communities indicate that most people in the Selat Village view the place of worship as a place that has a high purity value. The sanctity of the place of worship is believed by the people to be the place for the gathering of God Almighty in His manifestation. In other words, by maintaining the preservation of protected forests, the community also maintains the sanctity of a place of worship.

Place of worship is a sacred building owned by Hindu people, which is a place of worship of God or His-manifestation. The use of black-white clothes in the place of worship is a hallmark of God's power that serves as a spiritual security guard (guardian from spiritual world dimension), which is further expected that security and goodness can be established to obtain a harmonious life. The main task is to maintain the security of the yard or the environment. The worship in the forest as shown in Fig. 2.

\section{Fig. 2: The Place of Worship in the Forest}

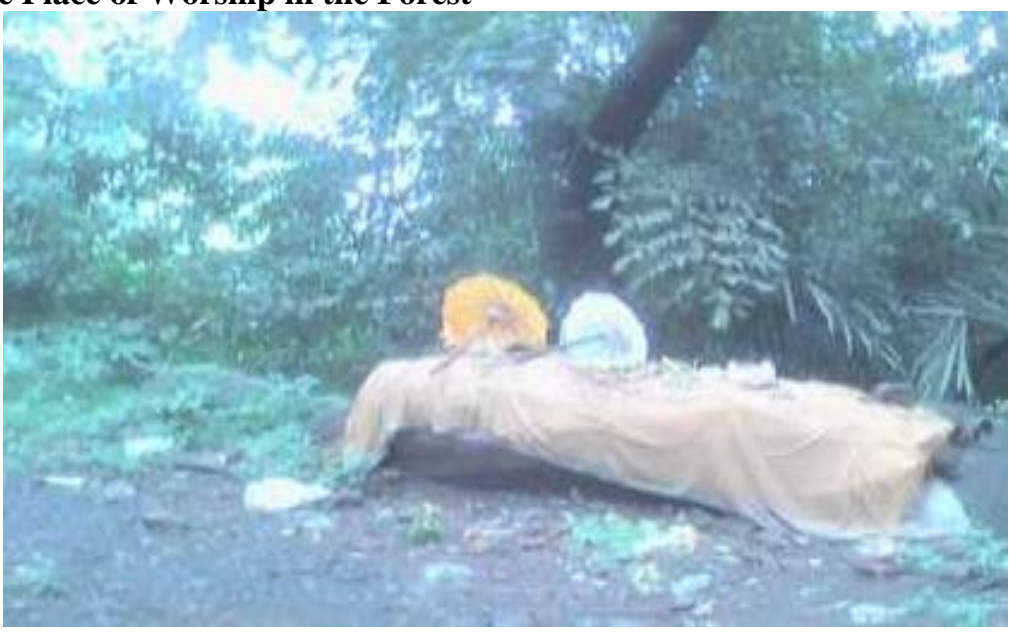


The use of Black-White Clothes for the Forest Guards

The form of activities regard to the existence and role of pecalang or guardian as an effort to maintain and protect the protection forest from damage. Based on the results of the study, it is found that most of the people in Selat Village stated that the guardian play a role in protecting the forest. The main reason for the establishment of pecalang is due to the deforestation. This guardian is also intended to assist the government in monitoring activities. Moreover, the number of forest police provided by the government is very limited in controlling the area of protection forest that is wide enough. In other words, they are an effective social organization of local community in controlling deforestation compared to forest police provided by the government. This finding was in line with the research of (Remegie \& Yansheng, 2008) finding that the local people were the primary managers of the forest management.

Another role of the guardian is to control community activities in protection forests. Everyday they always spend time visiting protection forests to ensure that no community is committing forest destruction or deforestation. Communities in the Selat Village who participate as the guardian are community representatives based on non-materialistic principles or self-interest to work and without any compulsion in performing duties and obligations as a Pecalang Jagawana or Forestry Guardian. The people who participate as forest guards are representatives of each hamlet that is directly adjacent to the protected forest area. Each hamlet proposed two representatives as forest guards in the Selat Village.

Other interesting findings in this study are related to the activities of the guardian which include the procurement of socialization of the community in Selat Village on the security of the forest and its security, regular patrolling twice a month, holding management meetings and members each month of at least one meeting to anticipate the findings in the field, and hold reforestation in the middle of the forest or at an agreed place. This shows that traditional forest management appears far more sustainable and operational that management by the forest police. Balinese guardian as social capital is fully trusted by the community (Arta, 2012). They have strong strength and charisma, making it easy to keep the community obedient and orderly. The existence of this guard is further a manifestation of a harmonious relationship between humans and fellow human beings, both the people within the Selat Village and those outside the village.

The guardian institution plays a major role in determining the course of custom activities. This guardian is a traditional security task force of Balinese people who have the authority to maintain the security and order of the region (Atmadja et al., 2013). They served to secure the forest known as Guardians Rangers. The use of a guardian polish trap means that they should always pay attention to the surrounding circumstances, in order to control the security. In accordance with the color of the black white on the cloth, a guardian must understand good and evil, and further through his intellectual maturity and alertness, can control security and order. A person who has used it and declared himself willing to take on a job as a guardian means that the person has dared to take risks against the consequences that may arise from his duties. In general, balinese guardian who use black white cltohes is someone who has the ability as a guard, has the authority in carrying out duties, wise, able to communicate with the community and are neutral or impartial. The use of black-white clothes on the forest guards as shown in Fig. 3. 
Fig. 3: The Use of Black-White Clothes for Forest Guards

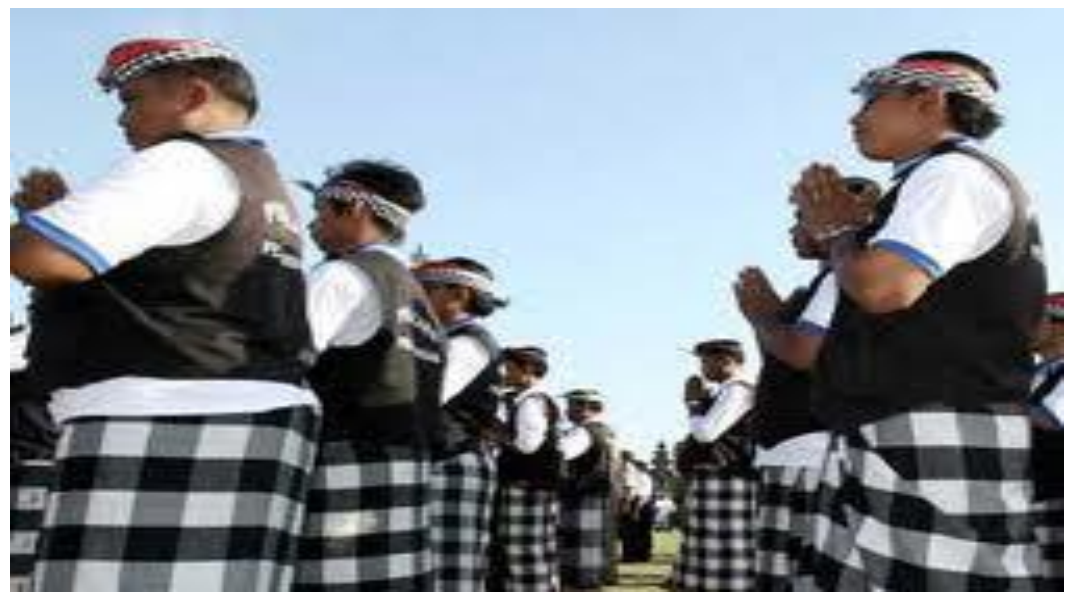

The use of black-white clothes on trees

In addition to the construction of shrines and the establishment of forest guards security units, the community through local spiritual figures also selected several trees which were considered to have high sacred values to be worn by black-white clothes. Selected trees are usually large, and also dense. The selected tree is then subjected to black-white clothes as a symbol of the sacredness of the tree. In the same field of study, Suda (2001, dalam Nurdjana et. al., 2005) assesses the use of tree poles in the effort to control the social so that people do not pass illegal logging. Realized or not by the community when they see a large tree that is black-white clothes, do not cut the tree, just picking the leaves they will not dare, without preceded by the request permission in the real world and spiritual world. In a sense, it means asking for a real permission to the owner or person who keeps the tree and then followed by prayer on the place of worship under the tree to ask permission in spiritual world. In line with that view, Nada (1991, dalam Nurdjana et. al., 2005) states that the purpose of Hindus performing prayers under a large tree worn by a black-white clothes is not to worship idols, but to express gratitude to God who has given mankind various kinds of trees so as to help his life in This world. The use of black-white cloth on the tree is a concrete manifestation of a harmonious relationship between humans and the environment. The sacred value of a tree that is subject to black-white clothes makes people reluctant, and even afraid to just approach the tree.

The results of interviews with local people who work as carpenters legally tell that when looking at the tree that is worn by the black-white clothes, it will understand that the tree is sanctified and considered sacred. Efforts to preserve the existing trees around humans, although in a small scope, will directly affect human life in the vicinity and indirectly associated with life on earth. Global warming due to the increase in greenhouse effect intensity by greenhouse gases is a negative impact caused by illegal logging of trees and forests. An intensive countermeasure is therefore important in a sustainable manner. One effort that has been implemented by Hindus in Bali is to apply environmental ethics based on the cultural landscape through local wisdom in Bali. The real form that has been done is the use of black-white clothes on trees that are considered to have a value of sanctity and significance for the lives of people and ecosystems around the tree.

The definition of the use of black-white clothes on a tree is related to the presence of trees in human life. Trees will be beneficial to human life if properly maintained, and if the 
maintenance is permeated by religious teachings well, then the maintainers will get better results. Conversely, if the tree is not maintained or no trees at all, then humans will have difficulty in life. Plants and trees have a sacred nature, and they are the savior of humanity. Plants and trees can also destroy the toxic effects on the atmosphere. Because they have fed and protected the universe, they are also called mothers. The use of black-white clothes on the tree as shown in Fig. 4.

Fig. 4: The Use of Black-White Clothes on Trees

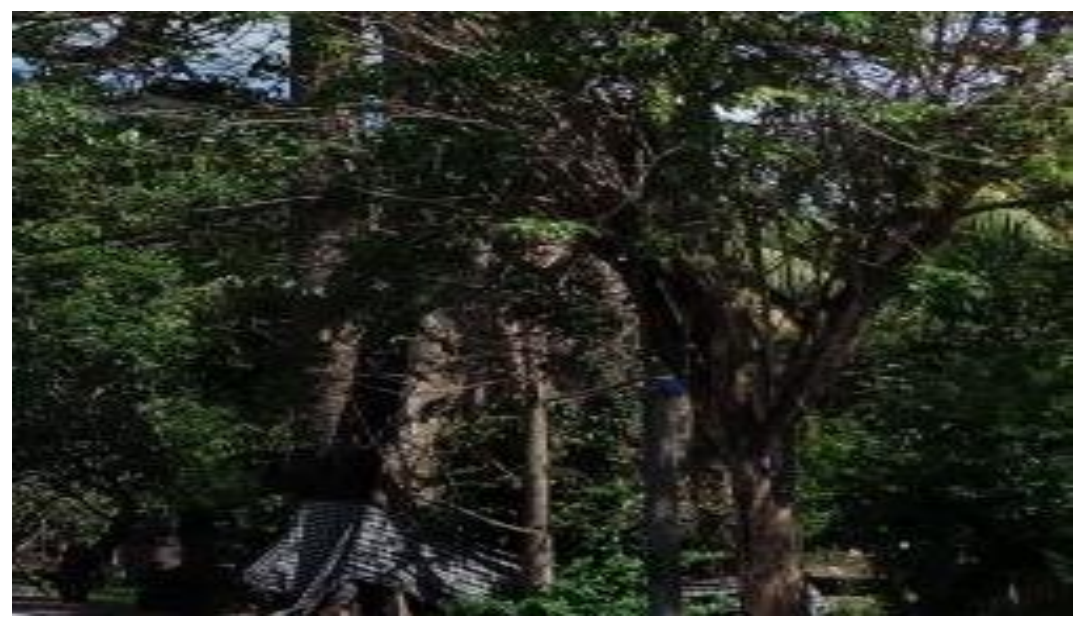

Paying attention to places, people and objects were worn or wearing a black-white clothes showing a state of a certain strength, having more authority than others, having a sacred or purified value, generates a sense of shame for most people who see it and have greatness which exudes a certain power. In other words, they are called numinous which means they reveal the secrets of the aspect of God's power. In essence, those wearing or wearing a black-white clothes always manifest themselves as a reality that is entirely different in level from the surrounding natural reality, that is what is sacred.

The forest plays an important role in the lives of the local communities as they mainly obtain numerous benefits either as direct or indirect benefits (Su et. al., 2011). Local forest management is essential for enhancing the sustainability of both communities livelihoods and reducing emmision from deforestation (Awung \& Marchant, 2016). Therefore, local communities need to manage forest resources to avoid negative impacts of deforestation.

\section{CONCLUSION}

Cultural landscapes are regarded as being 'at the interface between nature and culture. They represent a closely woven net of relationships, the essence of culture and people's identity. They are a symbol of the growing recognition of the fundamental links between local communities and their heritage, humankind and its natural environment. Thus, in anticipating deforestation, forestry programming and collaborating with the local communities is an urgent long-term forestry program oriented to the following key issues: (1) Countering the declining quality and quantity of forest resources, (2) Development of plantations, and (3) Development of functions and benefits of forest resources rationally for the economy and development In addition, also pay attention to consolidation of forest areas, 
combating unauthorized logging and timber smuggling, prevention of forest fires, forest and land rehabilitation, development of human resources, utilization of science and technology, the role of forestry research and development and increased participation, empowerment, welfare, education, health and social status of forest villagers or within forests to gain special priority in forestry programs.

\section{REFERENCE}

Arta, K. S. (2012). Civil, Political and Economic Community Collaboration in Utilizing Social Capital (in bahasa). Jurnal Ilmu Sosial Dan Humaniora, 1(2), 117-128.

Atmadja, A. T., Atmadja, N. B., \& Maryati, T. (2013). Sea Balinese Guardian: Traditional Security Task Force for Coast and Sea Environment Preservation (in bahasa). Jurnal Bumi Lestari, 13(1), 174-184.

Awung, N., \& Marchant, R. (2016). Investigating the Role of the Local Community as Co-Managers of the Mount Cameroon National Park Conservation Project. Environments, 3(4), 36.

Burirat, S., Thamsenamupop, P., \& Kounbuntoam, S. (2010). A Study of Local Wisdom in Management of the Community Forest in Ban Nong Hua Khon, Tambon Nong Muen Than, At Samat District, Roi-Et Province. Pakistan Journal of Social Sciences, 7(2), 123-128.

Christiawan, P. I., \& Lestari, N. W. S. (2015). Cultural Landscape of Traders Viewed from Tri Wara Concept in Traditional Market of Menanga Village (in bahasa). Media Komunikasi Geografi, 16(1), 27-38.

Forest Watch Indonesia. (2001). Portrait of Indonesia's Forest Condition (in bahasa). Bogor: Global Forest Watch.

Hidayati, D. (2016). Waning Value of Local Wisdom in The Management of Water Resources (in bahasa). Jurnal Kependudukan Indonesia, 11(1), 39-48.

Ministry of Forestry. (2015). Forest Area Statistics (in bahasa). Jakarta.

Nurdjana, I. G. M., Prasetyo, T., \& Sukardi. (2005). Corruption and Illegal Logging in a Decentralized System (in bahasa). Yogyakarta: Pustaka Pelajar.

Otieno, A. C., \& Buyinza, M. (2010). Collaborative Forest Management in Uganda: A strategy for controlling deforestation in West Bugwe Forest Reserve, Busia District. Research Journal of Applied Sciences.

Patten, D. T. (2016). The Role of Ecological Wisdom in Managing for Sustainable Interdependent Urban and Natural Ecosystems. Landscape and Urban Planning, 155, 3-10.

Remegie, N., \& Yansheng, G. (2008). Participation in Sustainable Tropical Forest Management. Journal of Economic Theory, 2(3), 95-100.

Sardiana, I. K., \& Dinata, K. K. (2010). Study of the Use of Plants in Ritual Activities (Upakara) by Hindus in Bali (in bahasa). Jurnal Bumi Lestari, 10(1), 123-127.

Sasaki, T. S., Ahmad, A. H., \& Ahmad, Z. A. (2011). ReDD Development in Cambodia-Potential Carbon Emission Reduction in ReDD Project. Formath, 10, 1-23.

Setiawan, H., Jaya, I. N. S., \& Puspaningsih, N. (2015). Deforestation Spatial Model In North Konawe And Konawe Districts South East Sulawesi Province (in bahasa). Media Konservasi, 20(2), 166-176.

Su, G. S., Macawile, J., Villarino, A., Agapito, J., \& Gomez, N. (2011). Recognizing Local People's Perceptions Towards Deforestation in the Philippines. Environmental Research 
Journal, 5(3), 131-135.

Sunderlin, W. D., \& Resosudarmo, I. A. (1997). The Rate and Causes of Deforestation in Indonesia: Review of Confusion and Resolution (in bahasa). Forestry, 9(9), 1-20.

Yamani, M. (2011). Local Law-Based Forest Protection Strategy in Eman Community of Custom Bengkulu Regional (in bahasa). Jurnal Hukum, 1(2), 175-192. 